\title{
NOTES
}

\section{Cytovaricin B, a New Inhibitor of JAK-STAT Signal Transduction Produced by Streptomyces torulosus}

\author{
Noriyuki Yamashita, KazUo Shin-ya, \\ Makoto Kitamura, Hiroshi WaKao, Keiko Furihata, \\ Kazuo Furihata, Yoichi Hayakawa, \\ Atsushi Miyajima and Haruo Seto* \\ Institute of Molecular and Cellular Biosciences, \\ The University of Tokyo, \\ Bunkyo-ku, Tokyo 113, Japan \\ Division of Agriculture and Agricultural Life Sciences, \\ The University of Tokyo, \\ Bunkyo-ku, Tokyo 113, Japan
}

(Received for publication February 14, 1997)

Cytokines govern the growth, differentiation and functional activity of cells in the haematopoietic and immune systems. Of these, interleukin-3 (IL-3) has a broad range of function, with actions on cells at various stages of haematopoietic development ${ }^{13}$.

Recently, attention has been focused on the role of the Janus kinase (JAK) family of kinases in cytokine action. Many cytokine receptors have now been shown to associate physically with and activate specific JAK kinases $^{2)}$. JAK kinases regulate latent, cytoplasmic transcription factors termed STATs (Signal transducers and activators of transcription). IL-3 and granulocytemacrophage colony-stimulating factor (GM-CSF) activate JAK2 and STAT5 ${ }^{3,4}$. Because many cytokines induce tyrosine phosphorylation in lymphoid progenitor cells, and constitutive tyrosine phosphorylation is commonly observed in B-lineage leukaemias ${ }^{5,6}$, attempts have been made to develop protein tyrosine kinase (PTK) blockers of leukaemia cell growth ${ }^{7,8}$. Specific tyrosine kinase blockers of JAK2 were reported to selectively inhibit leukaemic cell growth in vitro and in vivo by inducing programmed cell death, with no deleterious effect on normal haematopoiesis ${ }^{91}$.

In order to study the role of STAT5 in IL-3 signaling, and to find new growth inhibitors of leukaemic cells, we have screened inhibitors of STAT5 from microbial metabolites using a luciferase reporter system in IL-3 dependent $\mathrm{Ba} / \mathrm{F} 3$ cells. The cells were transfected with reporter plasmid consisting of luciferase gene under the control of the $\beta$-casein promoter having STAT5 binding sites. In this system, the expression of the luciferase activity is expected to be suppressed by inhibitors of JAK-STAT signal transduction.

In the course of our screening program using this system, we have found a new compound, cytovaricin B (1) from the culture broth of Streptomyces torulosus 3197-GM1. In this paper, we report the fermentation, isolation, physico-chemical properties, structure elucidation and inhibitory activity of $\mathbf{1}$.

Streptomyces torulosus 3197-GM1, which was isolated from a soil sample collected in Iwaki, Fukushima Prefecture, Japan, was inoculated in 500-ml Erlenmeyer flasks containing $100 \mathrm{ml}$ of a medium comprising of starch $2.5 \%$, soybean meal $1.5 \%$, dry yeast $0.2 \%$, and $\mathrm{CaCO}_{3} 0.4 \%$, the $\mathrm{pH}$ being adjusted to 6.2 before sterilization. The fermentation was carried out at $27^{\circ} \mathrm{C}$ for 5 days on a rotary shaker. The supernatant of cultured broth (1.6 liter) was extracted twice with ethyl acetate $(1$ liter $\times 2)$ at $\mathrm{pH} 7$. The organic layer was concentrated to dryness and the residue was applied to a silica gel column $(2 \times 30 \mathrm{~cm}$, Wakogel C-200). After washing the column with hexane $(200 \mathrm{ml})$, the active material was eluted with hexane-ethyl acetate $(3: 1,300 \mathrm{ml})$ and $n$-hexane-ethyl acetate $(2: 1,300 \mathrm{ml})$. The combined active eluate was concentrated to give a crude material, which was subjected to Toyopearl HW-40 column $(2 \times 70 \mathrm{~cm})$ chromatography using $80 \%$ aqueous acetone as the developing solvent. The active fractions were further purified by reversed phase HPLC, using a column of YMC Pack ODS $(2 \times 25 \mathrm{~cm}$, flow rate $5 \mathrm{ml} /$ minute $)$

Fig. 1. Structures of cytovaricin B (1) and cytovaricin (2).

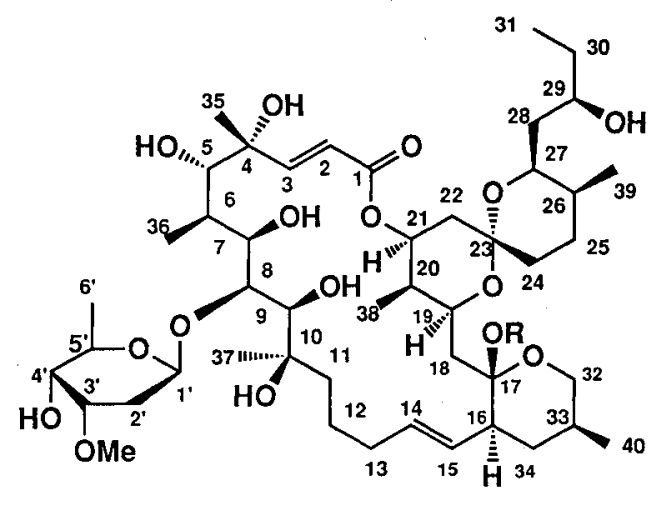

Cytovaricin $\mathrm{B}(\mathbf{1}): \mathbf{R}=\mathrm{CH}_{\mathbf{3}}$ Cytovaricin (2) $: \mathbf{R}=\mathrm{H}$ 
Table 1. Physico-chemical properties of cytovaricin B (1).

\begin{tabular}{ll}
\hline Appearance & Colorless amorphous powder \\
Optical rotation & {$[\alpha]_{\mathrm{D}}^{23}-9^{\circ}(c 0.1, \mathrm{CHCl})$} \\
MP $\left({ }^{\circ} \mathrm{C}\right)$ & $210 \sim 213$ \\
Formula & $\mathrm{C}_{48} \mathrm{H}_{82} \mathrm{O}_{16}$ \\
HR-FAB-MS $(m / z)$ & $915.5688(\mathrm{M}+\mathrm{H})^{+}$ \\
Calcd. & 915.5681 \\
$\mathrm{UV} \lambda_{\max } \mathrm{nm}(\varepsilon)$ in MeOH & $217(11,000)$ \\
IR $v_{\max }(\mathrm{KBr}) \mathrm{cm}^{-1}$ & $3400,1720,1270$ \\
\hline
\end{tabular}

with elution using $65 \%$ aqueous acetonitrile to give two fractions. The fraction containing 1 was evaporated in vacuo to give $8.0 \mathrm{mg}$ of pure 1 as a colorless amorphous powder, and the other fraction yielded a colorless powder $(10.2 \mathrm{mg})$ of cytovaricin $(2)^{10,11)}$.

Physico-chemical properties of 1 are summarized in Table 1.1 was soluble in $\mathrm{CHCl}_{3}$, EtOAc, $\mathrm{Me}_{2} \mathrm{CO}, \mathrm{MeOH}$ and DMSO, but insoluble in $n$-hexane and $\mathrm{H}_{2} \mathrm{O}$. The molecular formula of 1 was established as $\mathrm{C}_{48} \mathrm{H}_{82} \mathrm{O}_{16}$ from the HRFAB-MS and NMR spectral analyses. The IR spectrum of $\mathbf{1}$ showed the presence of an $\alpha, \beta$-unsaturated ester at $1720 \mathrm{~cm}^{-1}$. NMR data of 1 are summarized in Table 2 . The structure of 1 was determined by the analyses of DQF-COSY, HMQC and HMBC spectral data. All assignments were made based on comparison with 2 . An additional methoxy proton (17-OMe, $3.20 \mathrm{ppm})$ only observed in 1 was long-range coupled to a quaternary carbon $\mathrm{C}-17(101.1 \mathrm{ppm})$ in the HMBC spectrum of $\mathbf{1}$. Therefore, the tertiary hydroxyl group at $\mathrm{C}-17$ in $\mathbf{2}$ is concluded to be substituted by a methoxy group in 1. Thus, the structure of $\mathbf{1}$ was established as a lactol methyl ether of $\mathbf{2}$. In order to determine the stereochemistry of 1,2 was treated with methanol in the presence of Dowex $50\left(\mathrm{H}^{+}\right)$at $0^{\circ} \mathrm{C}$ for 2 hours to give a lactol methyl ether of $2^{12)}$. Comparison of the spectral data for the purified product from the reaction mixture and $\mathbf{1}$ showed complete agreement. Thus, the structure including the absolute stereochemistry of 1 was determined as shown in Fig. 1. Since the purification of $\mathbf{1}$ from the cultured broth was made in the absence of methanol, $\mathbf{1}$ is believed to be a natural product isolated from the nature for the first time.

The inhibitory effect of $\mathbf{1}$ in our system used for the screening was $32 \mu \mathrm{M}\left(\mathrm{IC}_{50}\right) .2$ was also active at the same concentration. In the evaluation system we employed $^{3,4,13)}$, directly inhibited STAT5 phosphorylation in naive $\mathrm{Ba} / \mathrm{F} 3$ cells without affecting JAK2 phosphorylation. Further studies on the mechanism of
Table 2. ${ }^{13} \mathrm{C}(125 \mathrm{MHz})$ and ${ }^{1} \mathrm{H}(500 \mathrm{MHz})$ NMR data of cytovaricin $\mathrm{B}(\mathbf{1})$ in $\mathrm{MeOH}-d_{4}$.

\begin{tabular}{|c|c|c|}
\hline No. & $\delta_{\mathrm{c}}$ & $\delta_{\mathrm{H}}$ \\
\hline 1 & 167.14 & \\
\hline 2 & 120.86 & $6.03 \mathrm{~d}$ \\
\hline 3 & 153.34 & $6.93 \mathrm{~d}$ \\
\hline 4 & 76.85 & \\
\hline 5 & 80.40 & $3.70 \mathrm{~m}$ \\
\hline 6 & 36.78 & $1.75 \mathrm{~m}$ \\
\hline 7 & 77.56 & $3.73 \mathrm{dd}$ \\
\hline 8 & 82.75 & $3.80 \mathrm{dd}$ \\
\hline 9 & 73.88 & 3.08 br s \\
\hline 10 & 75.84 & \\
\hline 11 & 41.75 & $1.32 \mathrm{~m}, 1.72 \mathrm{~m}$ \\
\hline 12 & 25.29 & $1.32 \mathrm{~m}$ \\
\hline 13 & 35.15 & $1.89 \mathrm{~m}, 2.12 \mathrm{~m}$ \\
\hline 14 & 133.44 & $5.33 \mathrm{ddd}$ \\
\hline 15 & 132.87 & $5.41 \mathrm{ddd}$ \\
\hline 16 & 47.12 & $2.33 \mathrm{~m}$ \\
\hline 17 & 101.09 & \\
\hline 18 & 37.29 & $1.78 \mathrm{~m}, 1.90 \mathrm{~m}$ \\
\hline 19 & 68.15 & $3.94 \mathrm{~m}$ \\
\hline 20 & 37.24 & $2.12 \mathrm{~m}$ \\
\hline 21 & 72.12 & 5.27 ddd \\
\hline 22 & 36.34 & $1.64 \mathrm{~m}, 1.71 \mathrm{~m}$ \\
\hline 23 & 98.75 & \\
\hline 24 & 30.74 & $1.40 \mathrm{~m}, 1.63 \mathrm{~m}$ \\
\hline 25 & 27.44 & $1.40 \mathrm{~m}, 2.13 \mathrm{~m}$ \\
\hline 26 & 31.93 & $2.13 \mathrm{~m}$ \\
\hline 27 & 70.27 & $4.06 \mathrm{ddd}$ \\
\hline 28 & 42.37 & $1.62 \mathrm{~m}, 1.39 \mathrm{~m}$ \\
\hline 29 & 71.94 & $3.70 \mathrm{~m}$ \\
\hline 30 & 32.00 & $1.46 \mathrm{~m}, 1.62 \mathrm{~m}$ \\
\hline 31 & 10.72 & $1.00 \mathrm{t}$ \\
\hline 32 & 68.15 & $3.15 \mathrm{t}, 3.54 \mathrm{dd}$ \\
\hline 33 & 31.35 & $1.78 \mathrm{~m}$ \\
\hline 34 & 36.78 & $1.42 \mathrm{~m}, 1.80 \mathrm{~m}$ \\
\hline 35 & 26.85 & $1.36 \mathrm{~s}$ \\
\hline 36 & 7.13 & $0.98 \mathrm{~d}$ \\
\hline 37 & 24.31 & $1.10 \mathrm{~s}$ \\
\hline 38 & 5.79 & $0.86 \mathrm{~d}$ \\
\hline 39 & 11.68 & $0.95 \mathrm{~d}$ \\
\hline 40 & 17.34 & $0.79 \mathrm{~d}$ \\
\hline $1^{\prime}$ & 100.71 & $4.90 \mathrm{dd}$ \\
\hline $2^{\prime}$ & 34.79 & $1.53 \mathrm{ddd}, 2.38 \mathrm{ddd}$ \\
\hline $3^{\prime}$ & 78.96 & $3.59 \mathrm{br} \mathrm{dd}$ \\
\hline $4^{\prime}$ & 74.27 & $3.18 \mathrm{dd}$ \\
\hline $5^{\prime}$ & 72.00 & $3.80 \mathrm{~m}$ \\
\hline $6^{\prime}$ & 18.53 & $1.25 \mathrm{~d}$ \\
\hline $3^{\prime} \mathrm{OMe}$ & 57.79 & $3.40 \mathrm{~s}$ \\
\hline 17OMe & 47.44 & $3.20 \mathrm{~s}$ \\
\hline
\end{tabular}

Chemical shifts were determined in ppm based on TMS as an internal standard.

inhibition for transcription of STAT5 and other biological activities are now under way.

\section{Acknowledgments}

This work was supported in part by a Grant-in-Aid for Scientific Research on Priority Areas to H.S., and by a Grant-in Aid for Scientific Research to K.S., The Ministry of Education, Science, Sports and Culture, Japan. This work was also 
supported by Research for the Future, Japan Society for the Promotion of Science to H.S., and Grant-in-Aid for Scientific Research to A.M.

\section{References}

1) Arai, K.; F. Lee, A. Miyajima, S. Miyatake, N. Arai \& T. Yokota: Cytokines: Coordinators of immune and inflammatory responses. Annu. Rev. Biochem. 59: 783 836,1990

2) Ihle, J. N.; B. A. Witthuhn, F. W. Quelle, K. Yamamoto, W. E. Thierfelder, B. Kreider \& O. SILVENNOINEN: Signaling by the cytokine receptor superfamily: JAKs and STATs. Trends Biochem. Sci. 19: $222 \sim 227,1994$

3) Quelee, F. W.; N. Sato, B. A. WitThuhn, R. C. Inhorn, M. Eder, A. Miyajima, J. D. Griffin \& J. N. Ihle: JAK2 associates with the bc chain of the receptor for granulocyte-macrophage colony-stimulating factor, and its activation requires the membrane-proximal region. Mol. Cel. Biol. 14: 4335 4341, 1994

4) Mru, A. L.-F.; H. WaKao, A.-M. O'Farrell, N. Harada \& A. MIYAJIMA: Interleukin-3, granulocyte-macrophage colony stimulating factor and interleukin-5 transduce signal through two STAT5 homologs. EMBO J. 14: $1166 \sim 1175,1995$

5) Grimaldi, J. C. \& T. C. Meeker: The t $(5 ; 14)$ chromosomal translocation in a case of acute lymphocytic leukemia joins the interleukin-3 gene to the immunoglobulin heavy chain gene. Blood 73: $2081 \sim 2085,1989$

6) DADI, H.; S. KE \& C. M. RoIFMAN: Interleukin 7 receptor mediates the activation of phosphatidylinositol-3 kinase in human B-cell precursors. Biochem. biophys. Res. Commun. 192: 459 464, 1993

7) Burke, T. R.; B. Lim, V. E. Marquez, Z. Li, J. B. Bolen, I. Stefanova \& I. D. Horak: Bicyclic compounds as ring-constrained inhibitors of protein-tyrosine kinase p56 ${ }^{\text {lck }}$. J. Med. Chem. 36: 425 432, 1993

8) Cushman, M.; H. Zhu, R. L. Geahlen \& A. J. Kraker: Synthesis and Biochemical evaluation of a series of aminoflavones as potential inhibitors of protein-tyrosine kinase $\mathrm{p} 56^{\mathrm{lck}}$, EGFr, and p60 $0^{\mathrm{v} \text {-src }}$. J. Med. Chem. 37: $3353 \sim 3362,1994$

9) Meydan, N.; T. Grumberger, H. Dadi, M. Shahar, E. Arpaia, Z. Lapidot, J. S. Leeder, M. Freeman, A. Cohen, A. Grazit, A. Levitzki \& C. M. Rolfman: Inhibition of acute lymphoblastic leukaemia by a JAK-2 inhibitor. Nature 379: 645 648, 1996

10) Kihara, T.; H. Kusakabe, G. Nakamura, T. Sakurai \& K. Isono: Cytovaricin, a novel antibiotic. J. Antibiotics 34: $1073 \sim 1074,1981$

11) Kihara, T.; M. Ubukata, J. Uzawa \& K. Isono: Biosynthesis and ${ }^{13} \mathrm{C}$ NMR assignment of cytovaricin, a neutral macrolide antibiotic. J. Antibiotics 42: $919 \sim 925$, 1989

12) Evans, D. A.; S. W. Kaldor, T. K. Jones, J. Clardy \& T. J. Stout: Total synthesis of the macrolide antibiotic cytovaricin. J. Am. Chem. Soc. 112: $7001 \sim 7031,1990$

13) MiU, A. L.-F.; H. WaKaO, T. Kinoshita, T. Kitamura \& A. Miyajima: Suppression of interleukin-3-induced gene expression by a $C$-terminal truncated Stat5: role of Stat5 in proliferation. EMBO J. 15: 2425 2433, 1996 